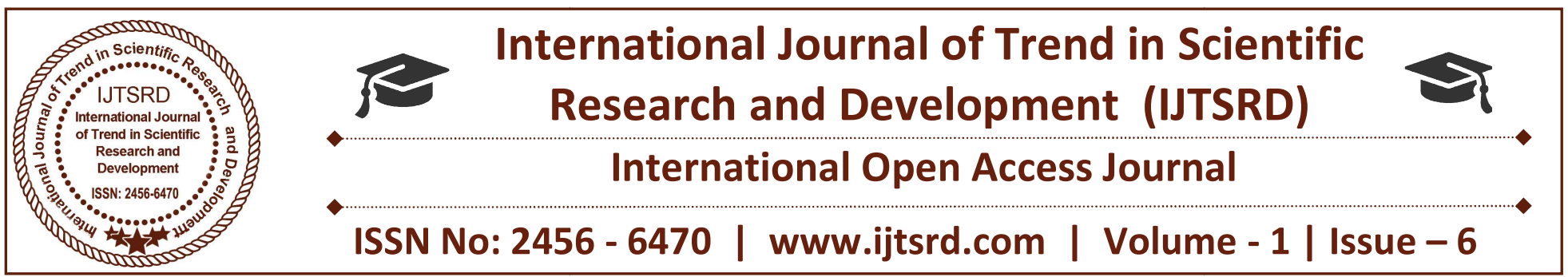

\title{
A Study on Stress Management among Employees in Nationalized Bank, Trichy City
}

\author{
K. Saravanan \\ Research Scholar, Bishop Heber \\ College(Autonomous), Trichy -17
}

\author{
Dr. K. MuthuLakshmi \\ Associate Professor of Commerce, \\ Bishop Heber College(Autonomous), Trichy -17
}

\begin{abstract}
This paper examines the level of stress and stress management among nationalized bank employees, Trichy City. Further, this study explores the level of effect personal factors on stress management. The stress management is measured by using the different dimension of respectful and responsible behavior, managing and communicating work, managing individual in a team and managing difficult situations. Stress can be defined as a reaction to a stimulus that disturbs our mental balance. It has its existence in everybody's life nowadays. Stress refers to the strain from the conflict between our external environment, leading to emotional and physical pressure. Stress can't be avoidable, but one can learn how to manage it. The data is collected using questionnaires from 100 nationalized bank employees who are randomly selected from the Tricy City and analyzed by using Statistical Package of Simple Percentage and ChiSquares Test.
\end{abstract}

Keywords: Anxiety, Stress, Stress Management, workplace stress

\section{INTRODUCTION}

Stress is simply the body's non - specific response to any demand made on it. Stress is not by definition synonymous with nervous tension or anxiety. Stress provides the means to express talents and pursue happiness. It can also cause exhaustion and illness, either physical or psychological, heart attack or accidents. The important thing to remember about stress it that certain forms are normal and essential. The result of continuing stress may because disruption is one or more of the following areas of health, physical, emotional, spiritual and social.

Today's age is "The Age of Anxiety" and this century is called "The Century of Stress". Today majority of people are in a state of Stress. Their fast-paced lifestyle places them under pressure to perform the best. Stress is often termed as twentieth century syndrome born out of man's race towards modern progress and its ensuring complexities. At one point or the other everybody suffers from stress. While the college students may experience stress in meeting the academic demands, the people in jobs and businessmen may suffer stress to reach office in time and to complete the projects on time. Even the household ladies may experience stress in managing the home affairs, look for a maid or servant. Most of us experience stress at one time or other; for without stress, there would be no life. Stress thus, has become a part of day-to-day living of every individual. A stress condition can be real or perceived. However, the brain does not differentiate between real and imagined stress. Right from the time of birth till the last breath every individual is invariably exposed to various stressful situations.

\section{STRESS MANAGEMENT:}

Stress management is dealing with stress in a positive way to ensure good health and general well being. Although stress in a changing world is inevitable executives have options on how to manage it. Stress management includes regular relaxation, physical exercise, talking with others, making time for social 
activities and reasonable self-statement. To master change, workers need to assess the need for stress management and develop strategies for reducing the impact of stressful changes at work. Learning changes at work. Learning to lower the stress load will enable staff to function and adapt more effectively.

Stress management helps executives to cope when change threatens to become overwhelming. Ideally one would like to see change unfold in a systematic way that allows one to remain calm, confident and optimistic. Stress can cause unpredictable and immeasurable problems to an individual and also to the organization. It can cause job-related problems like negating safety norms, indifferent job performance, quality compromises, not caring for others and surroundings, forgetfulness, uncharacteristic clumsiness, defying authority, defensiveness and violent behavior. Stress in an inevitable outcome of modern day complex life, in organizations after the arrival of banking companies in India.

\section{IMPORTANCE OF THE STUDY}

The present globalized economy and the entry of banking software have put the executives to enormous pressure due to acute competitions. This competition reflects on human resource and quality output. The competition is a continuous process and it has sustained its popularity in the market. Under these circumstances, the executives need extensive research as they are instrumental for maintaining a healthy organization. Delighted executives are the need of today's banking industry whose performance decides strategies, to create a conducive climate and environment which would enable them to ease out stress and strain for their better performance.

Although a lot of research has been conducted on 'Stress' over the last hundred years, some theories about it are now settled and accepted, while others are still being researched and debated. Researchers still continue to trace the causes and consequences of stress and strategies for coping with stress have not yet gained finality. Since then a great deal of further research has been conducted on this subject and new ideas have come to light. Though there are many researches going on, there are some missing links and gaps in the information provided by them. So an attempt is made in the present study to fill the gaps in the research and add new dimensions to the selected area of the subject.

\section{STATEMENT OF THE PROBLEM}

Stress is a dynamic condition in which a person faces with constraint and strains. Stress is the discomfort of an individual. Stress is a pressure condition causing hardship. It is an internal phenomenon of mental attitude. Stress is generally believed to have deleterious effect on health and performance. But a minimum level of stress is necessary for effective functioning and peak performance. It is the individuals reaction to stress which makes all the difference. Stress is a mental, emotional or physical reaction resulting from an individual's response to environmental pressure. It refers to pressure people feel in life. Different persons respond to stressful situation in different ways. It is important to distinguish between pressure and stress. Pressure is motivating, stimulating and energizing. But when pressure exceeds the ability to cope, stress is produced. Stress is an external force or pressure on the human mind. One should try to transform stress into vitality, energy into power and knowledge into wisdom. Stress can have serious consequences on both health and work performance.

\section{REVIEW OF LITERATURE}

Dr.Keith Davis And Dr.John W.Newstrom ( 1985) Stress is a condition of strain on one's emotion's thought processes, and Physical condition. When it is excessive, it can threaten one's ability to cope with the environment, "stress" is the general term applied to the pressures people feel in life. As a result of these pressures, employees develop various symptoms of stress that can harm their job performance. People who are stressed may become nervous and develop chronic worry. They are easily provoked to anger and are unable to relax. They may be uncooperative or use alcohol or drugs excessively. These conditions occur from other causes also, but they are common symptoms of stress.

Dr.M.J.Mathew (1993) Stress has a variety of meaning to people in the workplace. To the production manager in a chemical plant, it may be the tension of missing the shipping date of a large order for a major customer. To the business executive, it may be frustration associated with the inability to acquire sufficient short-term loans from banks to cover the operating needs, and so on.

In the words of szilagyi and Wallace, stress is an internal experience that creates a psychological or 
physiological imbalance within an individual and result from factors in the external environment, the organization, or the individual.

Anthony D'Souza (1993) Today's leaders not only live and work at a faster pace but they must also deal with uncertainty and change. They need effective methods for coping with the kind of stress that affects anyone in leadership positions. People popularly identify managing directors or chief executive officers (CEO) as those most susceptible to stress and disease. However, people at all levels of management find themselves exposed to comparable pressures.

Stephen P. Robbins (2005) Most of us are aware that employee stress is an increasing problem in organizations. Friends tells us they're stressed out from greater workloads and having to work longer hours because of downsizing at their company. Parents talk about the lack of job stability in today's world and reminisce about a time when a job with a large company implied lifetime security. We read surveys in which employees complain about the stress created in trying to balance work and family responsibilities. In this section we'll look at the causes and consequences of stress, and then consider what individuals and organizations can do to reduce it.

Stephen Palmer and Kristina Gyllensten (2005) did a study of review of literature to evaluate research relating to the role of gender in the level of workplace stress. A further aim was to review literature relating to stressors of particular relevance to working women. These stressors included, multiple roles, lack of career progress and discrimination and stereotyping. Much of the research indicated that women reported higher levels of stress compared to men. However, several studies reported no difference between the genders. Furthermore, the evidence for the adverse effects of multiple roles, lack of career progress and discrimination and stereotyping was inconsistent. Their review concluded that the evidence regarding the role of gender in workplace stress and stressors was inconsistent. Limitations of the research were highlighted and implications for practice were discussed.

Stress is a dynamic condition in which an individual is confronted with an opportunity, constrains, or demand related to what he or she desires and for which the outcome is perceived to be both uncertain and important. This is a complicated definition. Let's look at its components more closely.
Stress is not necessarily bad in and of itself. Although stress is typically discussed in a negative context, it also has a positive value. It's an opportunity when it offers potential gain. Consider, for example, the superior performance that an athlete or stage performer gives in "clutch" situations. Such individuals often use stress positively to rise to the occasion and perform at or near their maximum. Similarly, many professionals see the pressures of heavy workloads and deadlines as challenges that enhance the quality of their work and the satisfaction they get from their job.

Dr.C.B.Gupta (2006) Stress is an inevitable part of today's fast life. In this age of globalization and liberalization of the economy, competition among organizations has increased. Managers attempt to outperform one another to reach the top. Therefore, modern organizations are facing the problems of executive stress and burnout. Individuals and organizations have to pay economic and human cost due to their problems. Stress is the order of the day and it is impossible to be entirely without stress.

The word stress is derived from the Latin 'stringers' which means "to draw tight". Some define stress as the non-specific response of the body to any demands made on it. When the demands on an individual exceed his capability and adjustment resources stress occurs. Stress is different from anxiety which is a state of uncertainty. It is also differs from frustration which is blocked goal attainment.

Tamizharasi and Dr. Uma Rani (2014), it is been concluded that as the competitive environment, technological advancements, HR Practices, economic development, social developments are taking place day by day. Consequently, every employee is expected to work for long hours, perform multiple jobs, available for 24 hours in seven days. These reasons give a mentally as well as physical problems to the employees. When these problems increase, then it gives a pressure, strain, anxiety, tension, trauma to the employees and ultimately the productivity of the employee's decreases. More ever women get high stress than men.

\section{OBJECTIVES OF THE STUDY}

1. To identify personal factors and organizational factors causing stress among the employees of Nationalized Bank, Tricy City. 
2. To measure the impact of the stress management on organizational climate of Nationalized Bank, Tricy City.

\section{METHODOLOGY}

A research design is the arrangement of conditions for collection and analysis of data in a manner that aims to combine relevance to the research purpose with economy in procedure. The research has adopted descriptive research design to undertake the study on stress management of employees in Nationalized Bank, Trichy City. The researcher has collected the opinion of the employees of Nationalized Bank about the stress, causes and effects of its and portrays the responses of employees descriptively in this study.

\section{Sampling Techniques}

The sampling technique adopted was Stratified Random Sampling Technique. The population for this study consists of the nationalized bank employees in the Tricy City. The choice of respondents included in the survey is chosen at random and 100 nationalized bank employees were taken up as the sample.

\section{DATA COLLECTION}

\section{DATA ANALYSIS AND INTERPRETATION}

\section{A. Table: 1 Demographical Profile}

\begin{tabular}{|c|c|c|c|}
\hline & \multirow[t]{2}{*}{ Demographical Profile } & \multicolumn{2}{|c|}{$n=100$} \\
\hline & & Frequency & Percentage \\
\hline \multirow{4}{*}{$\begin{array}{l}\text { Designation of } \\
\text { Employees }\end{array}$} & Clerk & 45 & 45.0 \\
\hline & Probationary Officer & 35 & 35.0 \\
\hline & Assistant Manager & 15 & 15.0 \\
\hline & Manager & 5 & 5.0 \\
\hline \multirow[t]{4}{*}{ Age } & $<25$ & 5 & 5.0 \\
\hline & 26 to 35 & 28 & 28.0 \\
\hline & 36 to 45 & 37 & 37.0 \\
\hline & $>45$ & 30 & 30.0 \\
\hline \multirow{2}{*}{ Gender } & $\mathrm{F}$ & 48 & 48.0 \\
\hline & $\mathrm{M}$ & 52 & 52.0 \\
\hline \multirow[t]{5}{*}{ Salary } & $25000-35000$ & 35 & 35.0 \\
\hline & $35000-45000$ & 36 & 36.0 \\
\hline & $45000-55000$ & 12 & 12.0 \\
\hline & $55000-65000$ & 9 & 9.0 \\
\hline & $>65000$ & 8 & 8.0 \\
\hline \multirow[t]{3}{*}{ Education } & Diploma & 7 & 7.0 \\
\hline & $\mathrm{BE}$ & 34 & 34.0 \\
\hline & UG & 43 & 43.0 \\
\hline
\end{tabular}


International Journal of Trend in Scientific Research and Development (IJTSRD) ISSN: 2456-6470

\begin{tabular}{|l|l|l|l|}
\hline & PG & 11 & 11.0 \\
\hline & Other & 5 & 5.0 \\
\hline Marital Status & Married & 78 & 78.0 \\
\hline & Unmarried & 22 & 22.0 \\
\hline Experience & Up to 5 years & 15 & 15.0 \\
\hline & Up to 10 years & 22 & 22.0 \\
\hline & Up to 15 years & 35 & 35.0 \\
\hline & Up to 20years & 18 & 18.0 \\
\hline & 20 years above & 10 & 10.0 \\
\hline
\end{tabular}

\section{TABLE 2: PHYSICAL WORKING CONDITION OF THE ORGANIZATION}

\begin{tabular}{|c|c|c|}
\hline Satisfaction & $\begin{array}{l}\text { No. Of } \\
\text { respondents }\end{array}$ & Percentage \\
\hline Highly satisfied & 25 & 25 \\
\hline Satisfied & 35 & 35 \\
\hline Neutral & 10 & 10 \\
\hline Highly dissatisfied & 17 & 17 \\
\hline Dissatisfied & 13 & 13 \\
\hline Total & 100 & 100 \\
\hline
\end{tabular}

It is found from the survey that more than half of the respondents $35 \%$ are satisfied with the physical working condition of the organization, $25 \%$ of the respondents are highly satisfied with the physical working condition of the organization, Among all the respondents 13\% are neither satisfied nor dissatisfied with the physical working condition of the organization, $17 \%$ of the respondents are highly dissatisfied with physical condition provided and $13 \%$ respondents are dissatisfied with physical working condition of the organization.

TABLE 3: OPINION ABOUT THE JOB

\begin{tabular}{|c|c|c|}
\hline Particulars & $\begin{array}{l}\text { No. Of } \\
\text { respondents }\end{array}$ & Percentage \\
\hline Challenging & 34 & 34 \\
\hline Interesting & 36 & 36 \\
\hline Routine & 12 & 12 \\
\hline Boring & 8 & 8 \\
\hline Monotonous & 10 & 10 \\
\hline Total & 100 & 100 \\
\hline
\end{tabular}

It is clear from the survey that $34 \%$ of them feel the same job challenging, $36 \%$ of the respondents feel the job interesting, $12 \%$ of the respondents feel it routine, $8 \%$ of them feel it boring and while for $10 \%$ amongst the respondents the job is a monotonous one.

\section{TABLE 4: OPINION ABOUT THE COMPLETION OF THE WORK WITHIN THE SPECIFIED} TIME

\begin{tabular}{|c|c|c|}
\hline Satisfaction & $\begin{array}{l}\text { No. of } \\
\text { respondents }\end{array}$ & Percentage \\
\hline Strongly agree & 20 & 20 \\
\hline Agree & 24 & 24 \\
\hline Undecided & 7 & 7 \\
\hline Disagree & 27 & 27 \\
\hline Strongly disagree & 22 & 22 \\
\hline Total & 100 & 100 \\
\hline
\end{tabular}


It is observed from the survey that $20 \%$ of them strongly agree that they can complete the work at time, $24 \%$ of them agree that they can complete work at time, $7 \%$ of them have no idea, $22 \%$ of them strongly disagree that they cannot complete the work in time, $27 \%$ of them disagreed the completion of job in time.

TABLE 5: WORK OVERLOAD

\begin{tabular}{|c|c|c|}
\hline Satisfaction & $\begin{array}{c}\text { No. of } \\
\text { respondents }\end{array}$ & $\begin{array}{c}\text { Percentage } \\
\text { Strongly agree }\end{array}$ \\
\hline Agree & 35 & 35 \\
\hline Undecided & 59 & 39 \\
\hline Disagree & 11 & 5 \\
\hline Strongly disagree & 10 & 11 \\
\hline Total & 100 & 100 \\
\hline
\end{tabular}

From the above we can find that $35 \%$ of the respondents strongly agree that they have work overload, $39 \%$ of them agree that they have work overload, $5 \%$ of them don't have any idea, $11 \%$ disagree that they have work load.

TABLE 6: OPINION ABOUT INTERPERSONAL RELATIONSHIP

\begin{tabular}{|c|c|c|}
\hline Satisfaction & $\begin{array}{c}\text { No. of } \\
\text { respondents }\end{array}$ & Percentage \\
\hline Strongly agree & 30 & 30 \\
\hline Agree & 28 & 28 \\
\hline Undecided & 5 & 5 \\
\hline Disagree & 25 & 25 \\
\hline Strongly disagree & 12 & 12 \\
\hline Total & 100 & 100 \\
\hline
\end{tabular}

It is observed from the survey that $30 \%$ of the respondents strongly agree that they have strained interpersonal relationship, $28 \%$ of them agree that they have strained interpersonal relationship stress, $5 \%$ of them don't have any idea, $25 \%$ disagree that they have strained interpersonal relationship and $12 \%$ strongly disagree that they have strained interpersonal relationship.

TABLE 7: FAMILY FACTOR WHICH INFLUENCE STRESS

\begin{tabular}{|c|c|c|}
\hline Satisfaction & $\begin{array}{l}\text { No. of } \\
\text { respondents }\end{array}$ & Percentage \\
\hline Strongly agree & 35 & 35 \\
\hline Agree & 27 & 27 \\
\hline Undecided & 9 & 9 \\
\hline Disagree & 15 & 15 \\
\hline Strongly disagree & 14 & 14 \\
\hline Total & 100 & 100 \\
\hline
\end{tabular}

It is observed from the survey that $35 \%$ of the respondents strongly agree that they have influence stress, $27 \%$ of them agree that they have influence stress, $9 \%$ of them don't have any idea, $15 \%$ disagree that they have influence stress and 14\% strongly disagree that they have influence stress.

TABLE 8: ORGANIZATION POLICIES AND PROCEDURES ARE STRESS

\begin{tabular}{|c|c|c|}
\hline Satisfaction & $\begin{array}{c}\text { No. of } \\
\text { respondents }\end{array}$ & $\begin{array}{c}\text { Percentage } \\
\text { Strongly agree }\end{array}$ \\
\hline Agree & 27 & 27 \\
\hline Undecided & 62 & 42 \\
\hline Disagree & 14 & 6 \\
\hline Strongly disagree & 11 & 14 \\
\hline Total & 100 & 100 \\
\hline
\end{tabular}


It is observed from the survey that 27of the respondents strongly agree that the company's policies are stress , $42 \%$ of them agree that they have organization policies are stress , $6 \%$ of them have not idea it, $14 \%$ of them disagree that they have organization policy is free from stress

TABLE 9: PHYSICAL INCONVENIENCE DUE TO STRESS

\begin{tabular}{|c|c|c|}
\hline Satisfaction & $\begin{array}{c}\text { No. of } \\
\text { respondents }\end{array}$ & $\begin{array}{c}\text { Percentage } \\
\text { Strongly agree }\end{array}$ \\
\hline Agree & 36 & 36 \\
\hline Undecided & 79 & 39 \\
\hline Strongly disagree & 10 & 7 \\
\hline Disagree & 8 & 8 \\
\hline Total & 100 & 100 \\
\hline
\end{tabular}

It is observed from the survey that $36 \%$ of the respondents strongly agree that their physical inconvenience due to stress, $39 \%$ of the agree that their physical inconvenience due to stress and the $10 \%$ of the disagree that their physical inconvenience due to stress.

\section{TABLE 10: LEVEL OF STRESS}

\begin{tabular}{|c|c|c|}
\hline $\begin{array}{l}\text { Level of } \\
\text { stress }\end{array}$ & $\begin{array}{l}\text { No. Of } \\
\text { respondents }\end{array}$ & Percentage \\
\hline Very high & 36 & 36 \\
\hline High & 38 & 38 \\
\hline Moderate & 5 & 5 \\
\hline Low & 15 & 15 \\
\hline Very low & 6 & 6 \\
\hline Total & 100 & 100 \\
\hline
\end{tabular}

It is observed from the survey that $5 \%$ of the respondents have moderate level of stress, $36 \%$ of the respondents have Very high level of stress, $38 \%$ of the respondents have high level of stress, and only $6 \%$ of the respondents have very low level of stress.

\section{TABLE 11: ORGANIZATION STEPS TO MANAGE STRESS}

\begin{tabular}{|c|c|c|}
\hline Satisfaction & $\begin{array}{c}\text { No. of } \\
\text { respondents }\end{array}$ & Percentage \\
\hline Strongly agree & 35 & 35 \\
\hline Agree & 39 & 39 \\
\hline Undecided & 6 & 6 \\
\hline Disagree & 13 & 13 \\
\hline Strongly disagree & 7 & 7 \\
\hline Total & 100 & 100 \\
\hline
\end{tabular}

It is observed from the survey that $39 \%$ of the respondents agree that their organization steps to manage stress, $35 \%$ of the strongly agree that their organization steps to manage stress and the $13 \%$ of the disagree that their organization steps to manage stress.

TABLE 12: PROGRAMS THAT COULD BE ADOPTED TO MANAGE STRESS

\begin{tabular}{|l|c|c|}
\hline Particular & No. Of respondents & Percentage \\
\hline Employee counseling & 37 & 37 \\
\hline $\begin{array}{l}\text { Effective and training } \\
\text { development program }\end{array}$ & 24 & 24 \\
\hline Work groups & 17 & 17 \\
\hline Health clubs & 22 & 22 \\
\hline Total & 100 & 100 \\
\hline
\end{tabular}


It is observed from the survey that $24 \%$ of them recommend employee counseling, $12 \%$ of them need effective training, $23 \%$ need work groups and $24 \%$ need health groups.

\section{TABLE 13: STRATEGY TO REDUCE STRESS}

$\left(\mathrm{H}_{\mathrm{o}}\right)$ : The satisfaction level of stress management of employees toward strategy to reduce stress is very high.

\begin{tabular}{|c|c|c|c|c|c|}
\hline \multirow{2}{*}{\multicolumn{3}{|c|}{ Reduce Stress of Yoga }} & \multicolumn{2}{|c|}{ Respondents } & \multirow[t]{2}{*}{ Total } \\
\hline & & & Female & \multirow{2}{*}{$\begin{array}{l}\text { Male } \\
2\end{array}$} & \\
\hline & High & Count & 3 & & 5 \\
\hline & dissatisfaction & Expected Count & 2.4 & 2.6 & 5.0 \\
\hline & Dissatisfaction & Count & 3 & 3 & 6 \\
\hline & & Expected Count & 2.9 & 3.1 & 6.0 \\
\hline & Neutral & Count & 1 & 2 & 3 \\
\hline & & Expected Count & 1.4 & 1.6 & 3.0 \\
\hline & Satisfaction & Count & 12 & 10 & 22 \\
\hline & & Expected Count & 10.6 & 11.4 & 22.0 \\
\hline & High & Count & 29 & 35 & 64 \\
\hline & satisfaction & Expected Count & 30.7 & 33.3 & 64.0 \\
\hline \multirow{2}{*}{\multicolumn{2}{|c|}{ Total }} & Count & 48 & 52 & 100 \\
\hline & & Expected Count & 48.0 & 52.0 & 100.0 \\
\hline
\end{tabular}

\begin{tabular}{|l|c|c|c|}
\hline \multicolumn{4}{|c|}{ Chi-Square Tests } \\
\hline & Value & df & $\begin{array}{c}\text { Asymp. Sig. } \\
\text { (2-sided) }\end{array}$ \\
\hline Pearson Chi-Square & 1.119 & 4 & .891 \\
\hline & & & \\
\hline
\end{tabular}

Table 13(i) shows that the table value of $\chi^{2}$ is 9.49 at d.f. 4 and 5\% significance level is more than the calculated value of $\chi 2$ that is 1.119 which states that the hypothesis that the satisfaction level of Strategy to reduce stress of yoga is high proves true.

\begin{tabular}{|c|c|c|c|c|c|}
\hline \multirow{2}{*}{\multicolumn{3}{|c|}{ Reduce Stress of Meditation }} & \multirow{2}{*}{\multicolumn{2}{|c|}{ Respondents }} & \multirow{3}{*}{$\begin{array}{r}\text { Total } \\
7\end{array}$} \\
\hline & & & & & \\
\hline & High & Count & $\begin{array}{r}\text { Female } \\
3\end{array}$ & $\begin{array}{r}\text { Male } \\
4\end{array}$ & \\
\hline & dissatisfaction & Expected Count & 3.4 & 3.6 & 7.0 \\
\hline & Dissatisfaction & Count & 2 & 1 & 3 \\
\hline & & Expected Count & 1.4 & 1.6 & 3.0 \\
\hline & Neutral & Count & 1 & 2 & 3 \\
\hline & & Expected Count & 1.4 & 1.6 & 3.0 \\
\hline & Satisfaction & Count & 15 & 16 & 31 \\
\hline & & Expected Count & 14.9 & 16.1 & 31.0 \\
\hline & High satisfaction & Count & 27 & 29 & 56 \\
\hline & & Expected Count & 26.9 & 29.1 & 56.0 \\
\hline \multirow{2}{*}{\multicolumn{2}{|c|}{ Total }} & Count & 48 & 52 & 100 \\
\hline & & Expected Count & 48.0 & 52.0 & 100.0 \\
\hline
\end{tabular}




\begin{tabular}{|l|r|r|r|}
\hline \multicolumn{4}{|c|}{ Chi-Square Tests } \\
\hline & Value & df & $\begin{array}{c}\text { Asymp. } \\
\text { Sig. (2- } \\
\text { sided) }\end{array}$ \\
\hline Pearson Chi-Square & .754 & 4 & .944 \\
\hline
\end{tabular}

Table 13(ii) shows that the table value of $\chi^{2}$ is 9.49 at d.f. 4 and $5 \%$ significance level is more than the calculated value of $\chi^{2}$ that is 0.754 which states that the hypothesis that the satisfaction level of Strategy to reduce stress of meditation is high proves true.

\begin{tabular}{|c|c|c|c|c|c|}
\hline & \multirow{2}{*}{\multicolumn{2}{|c|}{ Reduce stress of Motivation }} & \multicolumn{2}{|c|}{ Respondents } & \multirow[t]{2}{*}{ Total } \\
\hline & & & Female & Male & \\
\hline & \multirow[t]{2}{*}{ High dissatisfaction } & Count & 3 & 2 & 5 \\
\hline & & Expected Count & 2.4 & 2.6 & 5.0 \\
\hline & \multirow[t]{2}{*}{ Dissatisfaction } & Count & 2 & 1 & 3 \\
\hline & & Expected Count & 1.4 & 1.6 & 3.0 \\
\hline & \multirow[t]{2}{*}{ Neutral } & Count & 2 & 3 & 5 \\
\hline & & Expected Count & 2.4 & 2.6 & 5.0 \\
\hline & \multirow[t]{2}{*}{ Satisfaction } & Count & 12 & 14 & 26 \\
\hline & & Expected Count & 12.5 & 13.5 & 26.0 \\
\hline & \multirow[t]{2}{*}{ high satisfaction } & Count & 29 & 32 & 61 \\
\hline & & Expected Count & 29.3 & 31.7 & 61.0 \\
\hline \multirow{2}{*}{\multicolumn{2}{|c|}{ Total }} & Count & 48 & 52 & 100 \\
\hline & & Expected Count & 48.0 & 52.0 & 100.0 \\
\hline
\end{tabular}

\begin{tabular}{|l|r|r|r|}
\hline \multicolumn{4}{|c|}{ Chi-Square Tests } \\
\hline & Value & df & $\begin{array}{c}\text { Asymp. } \\
\text { Sig. (2- } \\
\text { sided) }\end{array}$ \\
\hline Pearson Chi-Square & .876 & 4 & .928 \\
\hline
\end{tabular}

Table 13(iii) shows that the table value of $\chi^{2}$ is 9.49 at d.f. 4 and 5\% significance level is more than the calculated value of $\chi^{2}$ that is 0.876 which states that the hypothesis that the satisfaction level of Strategy to reduce stress of motivation is high proves true.

\section{Table 13(iv): Respondents Cross tabulation}

\begin{tabular}{|c|c|c|c|c|c|}
\hline \multirow{2}{*}{\multicolumn{3}{|c|}{ Reduce Stress of Counseling }} & \multicolumn{2}{|c|}{ Respondents } & \multirow[t]{2}{*}{ Total } \\
\hline & & & Female & Male & \\
\hline & \multirow[t]{2}{*}{ High dissatisfaction } & Count & 2 & 1 & 3 \\
\hline & & Expected Count & 1.4 & 1.6 & 3.0 \\
\hline & \multirow[t]{2}{*}{ Dissatisfaction } & Count & 1 & 3 & 4 \\
\hline & & Expected Count & 1.9 & 2.1 & 4.0 \\
\hline & \multirow[t]{2}{*}{ Neutral } & Count & 2 & 1 & 3 \\
\hline & & Expected Count & 1.4 & 1.6 & 3.0 \\
\hline & \multirow[t]{2}{*}{ Satisfaction } & Count & 12 & 13 & 25 \\
\hline & & Expected Count & 12.0 & 13.0 & 25.0 \\
\hline & \multirow[t]{2}{*}{ High satisfaction } & Count & 31 & 34 & 65 \\
\hline & & Expected Count & 31.2 & 33.8 & 65.0 \\
\hline \multirow{2}{*}{\multicolumn{2}{|c|}{ Total }} & Count & 48 & 52 & 100 \\
\hline & & Expected Count & 48.0 & 52.0 & 100.0 \\
\hline
\end{tabular}




\begin{tabular}{|l|c|c|c|}
\hline \multicolumn{3}{|c|}{ Chi-Square Tests } \\
& Value & df & Asymp. Sig. (2-sided) \\
\hline Pearson Chi-Square & 1.688 & 4 & .793 \\
\hline & & & \\
\hline
\end{tabular}

Table 13(iv) shows that the table value of $\chi 2$ is 9.49 at d.f. 4 and $5 \%$ significance level is more than the calculated value of $\chi 2$ that is 1.688 which states that the hypothesis that the satisfaction level of Strategy to reduce stress of counseling is high proves true.

\section{Table 13(v): Respondents Cross tabulation}

\section{Reduce stress of Indoor games}

\begin{tabular}{|c|c|c|c|c|}
\hline \multicolumn{2}{|l|}{ Reduce stress of Indoor games } & Female & Male & \\
\hline \multirow{2}{*}{ High dissatisfaction } & Count & 2 & 1 & 3 \\
\hline & Expected Count & 1.4 & 1.6 & 3.0 \\
\hline \multirow[t]{2}{*}{ Dissatisfaction } & Count & 3 & 3 & 6 \\
\hline & Expected Count & 2.9 & 3.1 & 6.0 \\
\hline \multirow[t]{2}{*}{ Neutral } & Count & 0 & 2 & 2 \\
\hline & Expected Count & 1.0 & 1.0 & 2.0 \\
\hline \multirow[t]{2}{*}{ satisfaction } & Count & 13 & 15 & 28 \\
\hline & Expected Count & 13.4 & 14.6 & 28.0 \\
\hline \multirow[t]{2}{*}{ high satisfaction } & Count & 30 & 31 & 61 \\
\hline & Expected Count & 29.3 & 31.7 & 61.0 \\
\hline \multirow[t]{2}{*}{ Total } & Count & 48 & 52 & 100 \\
\hline & Expected Count & 48.0 & 52.0 & 100.0 \\
\hline
\end{tabular}

\begin{tabular}{|l|r|r|r|}
\hline & Value & df & Asymp. Sig. (2-sided) \\
\hline Pearson Chi-Square & & 4 & .674 \\
\hline
\end{tabular}

Table (v) shows that the table value of $\chi^{2}$ is 9.49 at d.f. 4 and $5 \%$ significance level is more than the calculated value of $\chi 2$ that is 2.336 which states that the hypothesis that the satisfaction level of Strategy to reduce stress of indoor games is high proves true.

\section{CONCLUSION}

This study was conducted at a nationalized bank in Trichy City. The Main aim of study is to find out various reasons for the stress and stress level of employees. This study analysed that the employees faced stress in their working area due to their work pressure and inter personal conflicts. The present study is concluded that the employees stress is affecting by their behavior and morale. The stress can be divided to positive stress and negative stress. Positive stress of a employees happened due to their work hard and negative stress of employees due to negative thinking habit can also trigger stress. Negative stress is dangerous and it will give harmful effect to the organization. But stress can be controlled and reduced by motivation. This study identified that the stress can be reduced by yoga, meditation, motivation, counseling and indoor games. Effective stress management is something that our lives can go a little more smoothly. It has been proven that physical activities of would improve a person's mental health, help with depression, and relieve the side effects of stress. Stress management strategies are important in our daily lives. 


\section{REFERENCE}

1) Dr.Keith Davis And Dr.John W.Newstrom(1985), Human Behavior At Work: Organizational Behavior , ISBN 0-07-015566-6, (PP 468), New Delhi, Mcgraw-Hill.

2) Anthony D’Souza (1993), Leadership Book, ISBN 81-7108-116-9, (PP494), Mumbai city, J.N.Jarakkatt.

3) Mathew M.J. (1993) Organization theory and behavior book, ISBN 81-85176-97-3,(PP131), Jaipur city, S.K.Parnami

4) Stephen P. Robbins(2005), Organizational Behavior, ISBN-81-203-2875-2, (PP 569), New Delhi, Asoke K.Ghosh.

5) Stephen Palmer and Kristina Gyllensten,(2005) "The role of gender in workplace stress: a critical literature review" Health Education Journal, Vol. 64, No. 3, 2005, (PP.271-288).

6) Dr.C.BGupta (2006), Human Resource Management, ISBN:81-8054-452-4, (PP 33.1) New Delhi, Sultan Chand \& Sons

7) Tamizharasi and Dr. Uma Rani (2014) International Journal of Advanced Research in Computer and Communication Engineering, Vol. 3, Issue 1, January 2014, ISSN (Print):23195940,ISSN (Online): 2278-1021.

8) Geeta Kumari and K. M. Pandey (2011), Studies on Stress Management: A Case Study of Avatar steel Industries, Chennai, India International Journal of Innovation Management and Technology, Vol. 2, No. 5, October 2011. 